\title{
Re-discovering jaguar in remaining coastal Atlantic Forest in southeastern Brazil by non-invasive DNA analysis
}

\author{
Andiara Silos Moraes de Castro Souza', Bruno Henrique Saranholi ${ }^{1}$, Peter Gransden Crawshaw Jr. ${ }^{2}$, \\ Agustin Javier Paviolo ${ }^{3,4}$, Lilian Elaine Rampim ${ }^{5}$, Leonardo Sartorello ${ }^{5}$ \& Pedro Manoel Galetti Jr. ${ }^{1^{*}}$ \\ ${ }^{1}$ Universidade Federal de São Carlos, Departamento de Genética e Evolução, CEP 13565-905, \\ São Carlos, SP, Brazil \\ ${ }^{2}$ Instituto Chico Mendes de Conservação da Biodiversidade, Centro Nacional de Pesquisa e Conservação de \\ Mamíferos Carnívoros, CEP 12952-011, Atibaia, SP, Brazil \\ ${ }^{3}$ CONICET, Universidad Nacional de Misiones, Instituto de Biología Subtropical, Bertoni 85, \\ CP 3370, Puerto Iguazú, Misiones, Argentina \\ ${ }^{4}$ Asociación Civil Centro de Investigaciones del Bosque Atlántico, Bertoni 85, CP 3370, Puerto Iguazú, \\ Misiones, Argentina \\ ${ }^{5}$ Projeto Onçafari, CEP 05419-001, São Paulo, SP, Brazil \\ *Corresponding author: Dr. Pedro M. Galetti.Jr,e-mail:pmgaletti@ufscar.br
}

SOUZA, A. S. M. C., SARANHOLI, B. H., CRAWSHAW JR., P. G., PAVIOLO, A. J., RAMPIM, L. E., SARTORELLO, L., GALETTI Jr., P. M. Re-discovering jaguar in remaining coastal Atlantic Forest in southeastern Brazil by non-invasive DNA analysis. Biota Netropica. 17(2): e20170358. http://dx.doi.org/10.1590/1676-0611-BN-2017-0358

\begin{abstract}
Jaguar populations have been declining in Brazil mostly due to habitat loss and fragmentation, conflict with humans, poaching and reduction of prey. This is dramatically true in the Atlantic Forest, where occurrence of this large felid is now restricted to very few remaining areas. We used a non-invasive DNA analysis to search through felid scats collected in the Santa Virginia Unit (SVU) of the Serra do Mar State Park, to test for the potential presence of jaguar there. Our results indicated at least three individuals (two females and one male) inside SVU, thus confirming at least temporary presence of this top predator in this important protected area. It is now crucial to intensify studies in that area and surroundings, to evaluate the status of these individuals and identify conservation needs to urgently improve the prospects for the establishment of a resident population, allowing it to expand to adjoining units of the Serra do Mar State Park and Serra da Bocaina National Park.
\end{abstract}

Keywords: Panthera onca, fecal DNA, Santa Virginia Unit, Serra do Mar State Park

\section{Redescobrindo a onça-pintada em um remanescente de Mata Atlântica costeira no sudeste do Brasil por análise não-invasiva de DNA}

Resumo: As populações de onça-pintada têm sofrido declínio populacional devido a perda e fragmentação de habitat, por conflito com humanos, através da caça e pela redução da disponibilidade de suas presas. Isso é particularmente drástico no bioma Mata Atlântica, onde a ocorrência desse grande felino está atualmente restrita a poucos remanescentes. Utilizamos análise de DNA a partir de amostras de fezes para verificar a pontencial presença da espécie no Núcleo Santa Virgínia (NSV) do Parque Estadual da Serra do Mar. Os resultados indicaram a ocorrência pelo menos esporádica de três indivíduos (duas fêmas e um macho) no interior do NSV. Com isso, se torna crucial agora intensificar estudos naquela unidade e em áreas adjacentes, para avaliar a situação desses indivíduos e identificar as necessidades mais urgentes de conservação para melhorar a probabilidade de estabelecimento de uma população residente da espécie, permitindo que ela possa expandir para unidades de conservação vizinhas, como outros núcleos do Parque Estadual da Serra do Mar e o Parque Nacional Serra da Bocaina.

Palavras-chave: Panthera onca, DNA fecal, Núcleo Santa Virgínia, Parque Estadual da Serra do Mar 


\section{Introduction}

Jaguar (Panthera onca, Linnaeus 1758) populations have been steadily declining in Brazil, mainly since the mid-1900, due to habitat loss and fragmentation and because of conflicts with humans, from poaching (Zeller 2007, Beisiegel et al. 2012) and reduction of its prey (Sanderson et al. 2002, Beisiegel et al. 2012). Although currently considered near-threatened by IUCN (2016), the jaguar has been categorized as vulnerable in Brazil (Morato et al. 2013) and critically-endangered in the state of São Paulo (Bressan et al. 2009), where the largest contiguous portions of Atlantic Forest (AF) remain (Beisiegel et al. 2012). Originally distributed in several biomes in the Neotropical region, the jaguar is the only representative of the Panthera genus in the American continent (Sunquist \& Sunquist 2002 ) and has had its historic distribuiton reduced by $50 \%$ during the last 50 years (Sanderson et al. 2002, Zeller 2007).

Because of the high level of threat, of the high endemism rate and species richness, the Atlantic Forest is considered one of the five hotspots of biodiversity in the world (Myers et al. 2000), and is now reduced to about $16 \%$ of its original area, distributed in thousands of small remaining fragments (Ribeiro et al. 2009). According to Galetti et al. (2013), the Atlantic Forest can be the first tropical biome to lose its largest top predator, if the jaguar becomes extinct. At the moment, the species is present in only a few remainings areas (Beiseigel et al. 2012), with an estimated total population of less than 250 adult individuals, mostly living inside protected areas (Galetti et al. 2013). The largest remaining continuous block of Atlantic Forest is situated in the mountains of the Serra do Mar along the Atlantic coast, which in the state of São Paulo, is under protection of Serra do Mar State Park (PESM, acronym in Portuguese). The park encompasses a landscape mosaic of $332,000.00$ hectares (from $23^{\circ} 17^{\prime}$ to $2324^{\prime} \mathrm{S}$ and $45^{\circ} 03^{\prime}$ to $\left.40^{\circ} 11^{\prime} \mathrm{W}\right)$. Representing about $7 \%$ of the original extent of AF (Ribeiro et al. 2009), the park is responsible for maintaining a rich biodiversity of this biome (São Paulo 2006).

Because of its large size, the park was divided into ten administrative units, which include the Santa Virginia unit, where the study was conducted and which is recognized for its high biodiversity (Galetti et al. 2009, Rocha-Mendes et al. 2015). However, although the jaguar is believed to occur there (Rocha-Mendes et al. 2015), its presence has not been confirmed, after extensive camera trapping efforts between the years 2008-2011 (Crawshaw Jr., pers. commun.). In a recent camera trapping-based large scale survey on the jaguar occurrence, no individual was accounted in SVU (Paviolo et al. 2016).

In this study, we used a non-invasive DNA analysis to identify felid scats collected in the SVU, a recognized method for species identification (Farrel et al. 2000, Haag et al. 2009, Chaves et al. 2012, Miotto et al. 2014). Our results indicated at least three individuals (two females and one male) inside SVU, thus confirming the occurrence of this key top predator in this important protected area.

\section{Material and Methods}

\section{Fecal samples}

Twelve fecal samples were collected during 2012-2013 along roads and trails in the Santa Virginia unit of PESM; GPS coordinates were recorded for each sample. A small portion of each was preserved in $96 \%$ ethanol and kept in a $-20{ }^{\circ} \mathrm{C}$ freezer until DNA extraction, which was later carried out using the QIAamp DNA Mini kit (Qiagen), following its specific protocol. Felid tissue samples obtained from the bank maintained by the Centro Nacional de Pesquisa e Conservação de Mamíferos Carnívoros CENAP/ICMBIO were used as control and the DNA extraction followed Sambrok et al. (1989).

\section{Molecular species identification}

DNA amplification of two mitochondrial genes was used for species identification of each faeces sample. A Cyt $B$ primer pair developed by Farrel et al. (2001) was used to amplify a fragment of the Cytochrome $B$ gene, and the ATP6-DF3; ATP6-DR2 primer pair (Chaves et al. 2012) was used to amplify a fragment of the ATP6 gene, following the respective PCR protocols given by the already cited authors. All PCRs were carried out using a Veriti 96 Well Thermal Cycler (Applied Biosystems) and tissue sample DNA as a positive control.

The PCR products were sequenced in an ABI3730XL sequencer (Applied Biosystems). All the sequences obtained, as well as reference sequences obtained from GenBank, were analysed and aligned using the Geneious v.7.1.7 software (Kearse et al. 2012). Genetic distances between sequences were obtained by MEGA v.6 (Tamura et al. 2013), using Kimura 2 Parameters model (Kimura 1980). A Neighbor-Joining tree (Saitou \& Nei 1987), using 1000 replicates bootstrap, was constructed.

\section{Individual identification}

Ten microsatellite loci (FCA742, FCA146, FCA98, FCA740, FCA723, FCA453, FCA441, FCA391, FCA53 e FCA42) obtained from Menotti-Raymond et al. $(1999,2005)$ were used for the individual identification, following PCR protocols given in Haag et al. (2010).

The PCR products were genotyped using an ABI 3730xl sequencer (Applied Biosystems). The fecal samples were genotyped at least in five independent rounds for each microsatellite locus, and only those with five confirmed genotypes were considered. Genotyping used the Geneious v. 7.1.7 software (Kearse et al. 2012).

Based on the obtained genotypes, the individual identification was carried out using GIMLET v.1.3.3 (Valière 2002). The probability of two individuals in the population randomly sharing identical genotypes for all of the analyzed loci was analysed assuming the presence of siblings $\left(\mathrm{P}_{(\mathrm{ID}) \text { sibs }}\right)$, following Waits et al. (2001).

In addition, the presence of melanic individuals was tested using the Melacortin 1 receptor gene (MC1R), in which melanic individuals are homozygous for a $15 \mathrm{bp}$ delection while the wild body pattern could be either wild allele homozygous or heterozygous (Eizirik et al. 2003, Haag et al. 2010). The allele pattern was identified in the Geneious software (Kearse et al. 2012).

\section{Sexing and Kinship}

The amelogenin gene was used to identify sex of the identified individuals, following Pilgrim et al. (2005). Each sexed individual was confirmed through three independent PCRs.

Kinship was analysed using the ML-Relate software (Kalinowski et al. 2006), in which unrelated (UN), half-sibling (HS), full-sibling and/or parental-offspring (FS/PO) individuals were categorized.

\section{Results and Discussion}

Both fragments from ATP6 and $\mathrm{Cyt} B$ gene were successfully amplified for all 12 fecal samples. Blasting these sequences against the reference sequences obtained from blood samples and from GenBank, three of them were identified as belonging to jaguar, and nine from Puma concolor. The neighbor-joining-tree recovered these three jaguar samples within the group of Panthera onca (Figure 1), reinforcing that the method used was able to correctly identify the species who deposited the faeces collected. The ATP 6 and $C y t B$ gene have been previously used for felid identification (Chaves et al. 2012, Miotto et al. 2014, Wultsch et al. 2016), and proved to be a powerful molecular marker for this group of carnivores. 
The microsatellite analysis of the three jaguar samples identified three different individuals, based on the genotypes produced by the ten loci used, with significant probability $\left(\mathrm{P}_{(\mathrm{ID}) \mathrm{SIBS}}=0,0096\right)$. All three individuals showed at least one different allele for each locus analysed (Table 1). These results are quite surprising and indicate that three individuals are at least temporarily using the SVU (Figure 2). The presence of this large carnivore highlights the importance of this conservation unit and that it maintains a high degree of habitat integrity, with its high species diversity (Ripple et al. 2014, Rocha-Mendes et al. 2015). Moreover, this fact likely ensures more stability to this ecosystem since the jaguar has an important role on a top-to-down population control (Terborgh et al. 2001). Testing for body color pattern, no mutational signal ( $15 \mathrm{bp}$ deletion) in the melanism-related MC1R gene (Eizirik et al. 2003) was observed, suggesting the absence of melanism among the identified individuals.
Two females and one male were identified, after sexing with the amelogenin gene. Although the presence of two females may suggest some level of residence in the area, this remains to be investigated. The partnership analysis showed no kin relation among these animals, being not able to detect philopatry which might support an idea of residence. Therefore, the presence of jaguar in Santa Virginia increases the importance of this area for conservation of PESM, with a possibility, if this incipient potential population is well protected, to serve as a source area for adjacent conservation units, including other sectors of PESM (Cunha, Picinguaba, Caraguatatuba) and the Serra da Bocaina National Park. Thus, it is our recommendation that more efforts are concentrated in the SVU and neighboring areas, using all methods available, including track and scat surveys, camera traps, and, as possible, GPS-satellite telemetry to collect more information on the status of jaguar in the area, and direct conservation efforts to ensure the presence

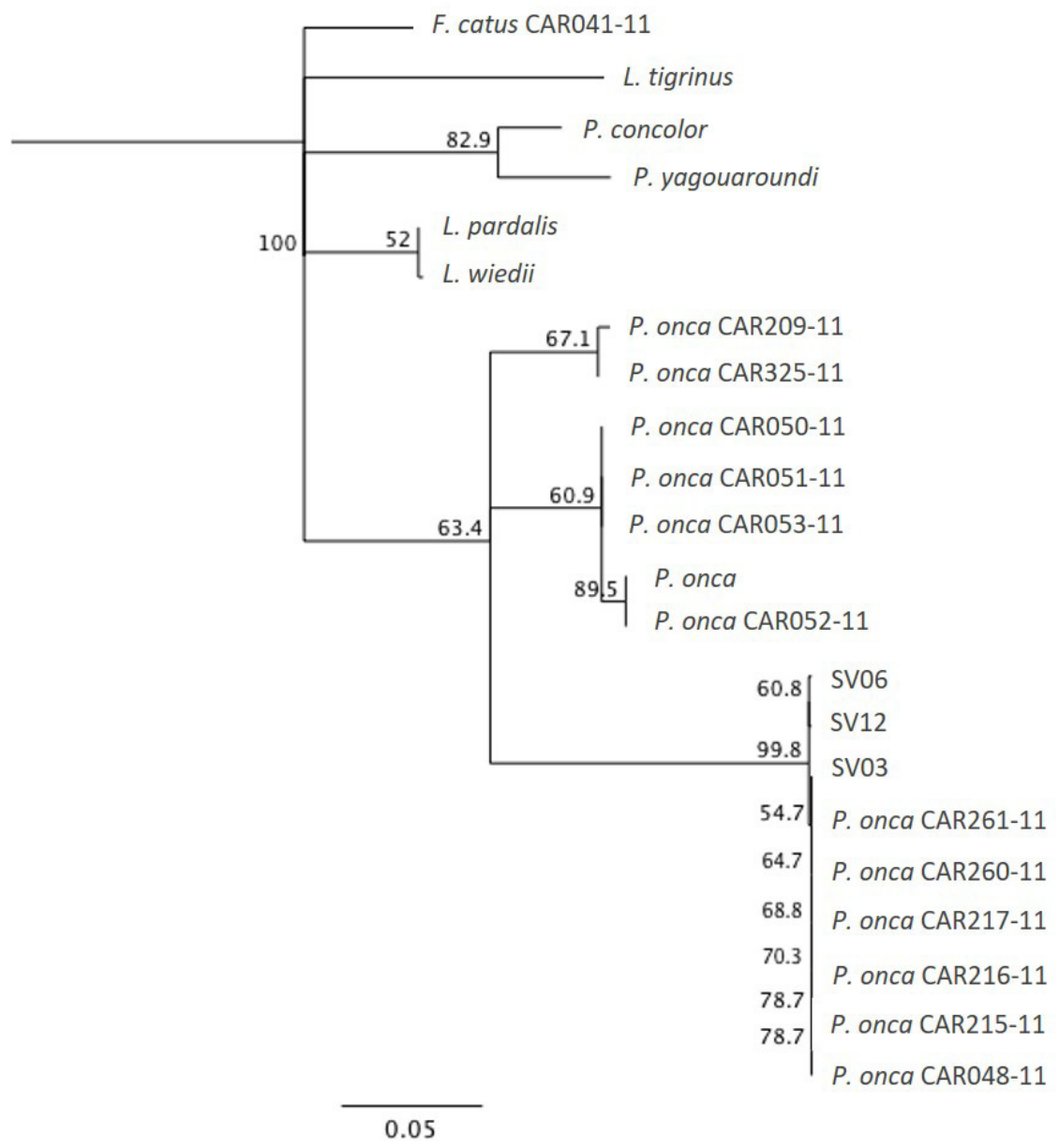

Figure 1 - Neighbor Joining tree highlighting the Panthera onca group. SV03, SV06 and SV12 sequences obtained from three fecal samples in the Santa Virginia Unit (SVU); P. onca (CAR048-11, CAR050-11- CAR053-11, CAR215-11- CAR217-11, CAR209-11, CAR260-11, CAR261-11 e CAR325-11) and F. catus (CAR051-11) sequences obtained in the BOLD systems; $L$. trigrinus, P. concolor, P. yagouaroundi, L. pardalis, L. wiedii and $P$. onca sequences obtained here from tissue samples.

Table 1 - Individual microsatellite alleles from the 10 loci genotyped. The "-" representes non-confirmed genotype.

\begin{tabular}{|c|c|c|c|c|c|c|c|c|c|c|c|}
\hline & \multicolumn{11}{|c|}{ Microsatellite loci } \\
\hline & & FCA441 & FCA391 & FCA98 & FCA42 & FCA53 & FCA723 & FCA740 & FCA742 & FCA453 & FCA146 \\
\hline Sample & Sex & Genotype & Genotype & Genotype & Genotype & Genotype & Genotype & Genotype & Genotype & Genotype & Genotype \\
\hline SM3 & $\mathrm{F}$ & $161 / 161$ & - & $189 / 189$ & $276 / 276$ & $214 / 218$ & - & $246 / 258$ & $127 / 205$ & $186 / 210$ & $185 / 185$ \\
\hline SM6 & $\mathrm{F}$ & $153 / 153$ & $197 / 269$ & $183 / 186$ & - & $218 / 226$ & $177 / 177$ & $206 / 258$ & $127 / 197$ & $210 / 210$ & $164 / 164$ \\
\hline SM12 & M & $157 / 157$ & $237 / 241$ & $183 / 183$ & $244 / 248$ & - & - & $190 / 190$ & $133 / 137$ & $210 / 226$ & $149 / 149$ \\
\hline
\end{tabular}




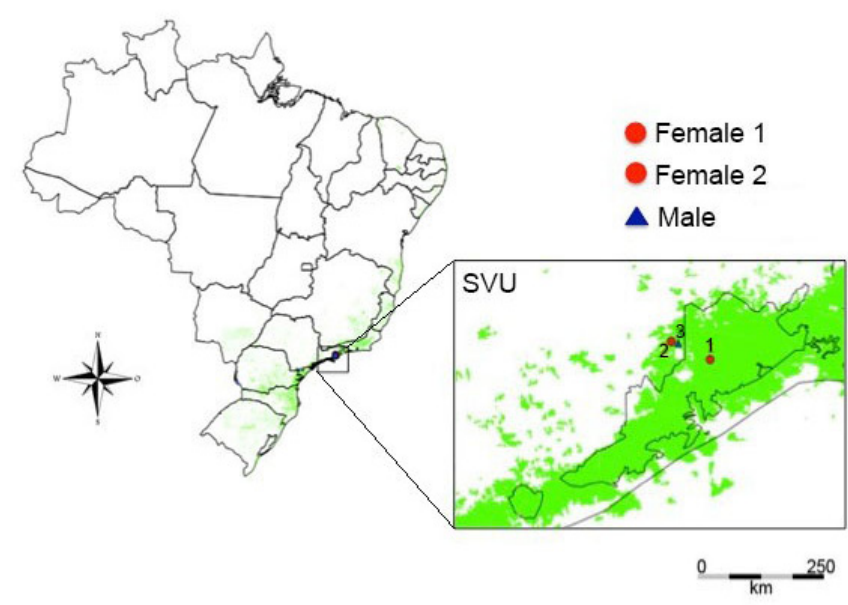

Figure 2 - Santa Virgínia Unit (SVU) in the Brazilian southeastern coast (São Paulo state), and the location of the three DNA identified jaguar faeces samples: (1) Female 1; (2) Female 2; (3) Male.

of the species in the region. This continuum of the Serra do Mar Atlantic Forest is considered high priority for conservation of this species (Zeller 2007, Paviolo et al. 2016) and our results can provide new momentum to implement an efficient management plan for the UC - SVU, taking into consideration all the requirements for the long term persistence of the jaguar.

\section{Acknowledgements}

The authors thank João Paulo Villani, Director of Núcleo Santa Virgínia and COTEC for collection permission. CENAP (Centro Nacional de Pesquisa e Conservação de Mamíferos Carnívoros) for providing samples used in control tests and as reference samples. This work is due to Sisbiota network - Top Predators, and the authors are thankful to Fundação de Amparo à Pesquisa do Estado de São Paulo (FAPESP - 2010/52315-7) and Conselho Nacional de Desenvolvimento Científico e Tecnológico (CNPq - 563299/2010-0) for financial support. ASMCS thanks FAPESP (2012/00534-2), BHS thanks FAPESP (2013/24453-4) and PMGJr thanks CNPq (308385/2014-4).

\section{Author Contributions}

a) Substantial contribution to the conception and design of the work: Andiara Silos Moraes de Castro e Souza and Pedro Manoel Galetti Jr.; b) Contribution to data acquisition: Andiara Silos Moraes de Castro e Souza, Bruno Henrique Saranholi and Pedro Manoel Galetti Jr.; c) Contribution in the analysis and interpretation of data: Andiara Silos Moraes de Castro e Souza, Bruno Henrique Saranholi, Peter G. Crawshaw Jr. and Pedro Manoel Galetti Jr.;

d) Contribution in the writing of the work: Andiara Silos Moraes de Castro e Souza, Bruno Henrique Saranholi, Peter G. Crawshaw Jr., Agustin Paviolo, Lilian Elaine Ranpim, Leonardo Sartorello, Pedro Manoel Galetti Jr.; e) Contribution in critical review adding intellectual content: Andiara Silos Moraes de Castro e Souza, Bruno Henrique Saranholi, Peter G. Crawshaw Jr., Agustin Paviolo, Lilian Elaine Ranpim, Leonardo Sartorello, Pedro Manoel Galetti Jr.

\section{Conflicts of interest}

The author(s) declare(s) that they have no conflict of interest related to the publication of this manuscript.

\section{References}

BEISIEGEL, B.M., SANA, D.A. \& MORAES-JÚNIOR, E.A. 2012. The jaguar in the Atlantic Forest. Cat News Special Issue. 7:14-18.

BRESSAN, P.M., KIERULFF, M.C.M. \& SUGIEDA, A.M. 2009. Fauna ameaçada de extinção no Estado de São Paulo. São Paulo: Fundação Parque Zoológico de São Paulo, Secretaria do Meio Ambiente.

CHAVES, P.B., GRAEFF, V.G., LION, M.B., OLIVEIRA, L.R. \& EIZIRIK, E. 2012. DNA barcoding meets molecular scatology: short mtDNA sequences for standardized species assignment of carnivore noninvasive samples. Mol. Ecol. Resour. 12(1): 18-35.

EIZIRIK, E., YUHKI, N., JOHNSON, W.E., MENOTTI-RAYMOND, M., HANNAH, S.S. \& O'BRIEN, S.J. 2003. Molecular Genetics and Evolution of Melanism in the Cat Family. Curr. Biol. 13.5(4): 448-453.

FARRELL, L.E., ROMAN, J. \& SUNQUIST, M. E. 2000. Dietary separation of sympatric carnivores identified by molecular analysis of scats. Mol. Ecol. 9(10): 1583-1590.

GALETTI, M., EIZIRIK, E., BEISIEGEL, B., FERRAZ, K., CAVALCANTI, S. SRBEK-ARAUJO, A.C, CRAWSHAW, P., PAVIOLO, A., GALETTI jr., P.M., JORGE, M.L., MARINHO-FILHO, J., VERCILLO, U. \& MORATO, R. 2013. Atlantic rainforest's jaguars in decline. Science. 342(6161):930-930.

HAAG, T., SANTOS, A.S., SANA, D.A., MORATO, R.G., CULLEN jr., L. CRAWSHAW JR, P.G., DE ANGELO, C., DI BITETTI, M.S., SALZANO, F.M. \& EIZIRIK, E. 2010. The effect of habitat fragmentation on the genetic structure of a top predator: loss of diversity and high differentiation among remnant populations of Atlantic Forest jaguars (Panthera onca). Mol. Ecol. 19: 4906-4921.

HAAG, T., SANTOS, A. S., DE ANGELO, C., SRBEK-ARAUJO, A. C., SANA, D. A., MORATO, R. G., SALZANO, F.M. \& EIZIRIK, E. 2009. Development and testing of an optimized method for DNA-based identification of jaguar (Panthera onca) and puma (Puma concolor) faecal samples for use in ecological and genetic studies. Genetica. 136(3): 505-512.

IUCN. The IUCN Red List of Threatened Species. Version 2016-2.<www.iucnredlist. org >. Ultimo acesso em 07/03/2017.

KALINOWSKI, S.T., WAGNER, A.P. \& TAPER, M.L. 2006. ML- Relate: a computer program for maximum likelihood estimation of relatedness and relationship. Mol. Ecol. Notes. 6(2): 576-579.

KEARSE, M., MOIR, R., WILSON, A., STONES-HAVAS, S., CHEUNG, M. STURROCK, S., BUXTON, S., COOPER, A., MARKOWITZ, S., DURAN, C., THIERER, T., ASHTON, B., MENTJIES, P. \& DRUMMOND, A. 2012. Geneious Basic: an integrated and extendable desktop software platform for the organization and analysis of sequence data. Bioinformatics. 28(12): 1647-1649.

KIMURA, M. 1980. A simple method for estimating evolutionary rates of base substitutions through comparative studies of nucleotide sequences. J. Mol. Evol. 16:111-120.

MENOTTI-RAYMOND, M., DAVID, V.A., LYONS, L.A., SCHÄFFER, A.A., TOMLIN, J.F., HUTTON, M.K. \& O’BRIEN, S.J. 1999. A genetic linkage map of microsatellites in the domestic cat (Felis catus). Genomics. 57(1): 9-23.

MENOTTI-RAYMOND, M.M., DAVID, V.A., WACHTER, L.L., BUTLER, J.M. \& O'BRIEN, S.J. 2005. An STR forensic typing system for genetic individualization of domestic cat (Felis catus) samples. J. Forensic. Sci Soc. 50: 1061-1070.

MIOTTO, R.A., CERVINI, M., KAJIN, M., BEGOTTI, R. A. \& GALETTI, P. M 2014. Estimating puma Puma concolor population size in a human-disturbed landscape in Brazil, using DNA mark-recapture data. Oryx. 48(02): 250-257.

MORATO, R.G., BEISIEGEL, B.M, RAMALHO, E.E., DE CAMPOS, C.B. \& BOULHOSA, R.L.P. 2013. Avaliação do risco de extinção da Onça-pintada Panthera onca (Linnaeus, 1758) no Brasil. Biodiversidade Brasileira. 1:122-132.

MYERS, N., MITTERMEIER, R.A., MITTERMEIER, C.G., DA FONSECA, G.A $\&$ KENT, J. 2000. Biodiversity hotspots for conservation priorities. Nature. 403(6772): 853-858

PAVIOLO, A., DE ANGELO, C., FERRAZ, K.M., MORATO, R.G., PARDO, J.M., SRBEK-ARAUJO, A.C., BEISIEGEL, B.M., LIMA, F., SANA, D., DASILVA, M.X., VELÁZQUEZ, M.C, CULLEN, L., CRAWSHAW jr, P., JORGE, M.L.S.P, GALETTI, P.M, DI BITETTI, M., DE PAULA, R.C., EIZIRIK, E., AIDE, M.T., CRUZ, P., PERILLI, M., SOUZA, A.S.M.C., QUIROGA, V., NAKANO, E., PINTO, F.R., FÉRNADEZ, S., COSTA, S., MORAES jr, E. \& AZEVEDO, F. 
2016. A biodiversity hotspot losing its top predator: The challenge of jaguar conservation in the Atlantic Forest of South America. Scientific Reports. 6.

PILGRIM, K.L., MCKELVEY, K.S., RIDDLE, A.E. \& SCHWARTZ, M.K. 2005. Felid sex identification based on noninvasive genetic samples. Mol. Ecol. Notes. 5: 60-61.

RIBEIRO, M.C., METZGER, J.P., MARTENSEN, A.C., PONZONI, F.J. \& HIROTA, M. M. 2009. The Brazilian Atlantic Forest: How much is left, and how is the remaining forest distributed? Implications for conservation. Biol. Conserv. 142(6):1141-1153.

RIPPLE, W.J., ESTES, J.A., BESCHTA, R.L., WILMERS, C.C., RITCHIE, E.G., HEBBLEWHITE, M., BERGER, J., ELMHAGEN, B., LETNIC, M., NELSON, M.P., SCHMITZ, O.J., SMITH, D.W., WALLACH, A.D. \& WIRSING, A.J. 2014. Status and ecological effects of the world's largest carnivores. Science. 343: 1241484.

ROCHA-MENDES, F., NEVES, C.L., NOBRE, R.D.A., MARQUES, R.M., BIANCONI, G.V. \& GALETTI, M. 2015. Non-volant mammals from Núcleo Santa Virgínia, Serra do Mar State Park, São Paulo, Brazil. Biota Neotrop. 15(1) http://www.biotaneotropica.org.br/v15n1/pt/fullpaper?bn00715012015+en (último acesso em 01/12/2016).

SAITOU, N. \& NEI, M. 1987. The neighbor-joining method: a new method for reconstructing phylogenetic trees. Mol. Biol. Evol. 4(4): 406-425.

SAMBROOK, J., FRITSCH, E. F. \& MANIATIS, T. 1989. Molecular cloning. Vol. 2. New York: Cold spring harbor laboratory press.

SANDERSON, E.W., REDFORD, K.H., CHETKIEWICZ, C.L.B., MEDELLIN, R.A., RABINOWITZ, A.R., ROBINSON, J.G. \& TABER, A.B. 2002. Planning to save a species: the jaguar as a model. Conserv. Biol. 16(1):58-72.

SÃO PAULO. 2006. Secretaria do Meio Ambiente. Plano de Manejo do Parque Estadual da Serra do Mar. São Paulo: Instituto Florestal. 445p.
SUNQUIST, M. \& SUNQUIST, F. 2002. Wild cats of the world. University of chicago press.

TAMURA, K., STECHER, G., PETERSON, D., FILIPSKI, A. \& KUMAR, S. (2013). MEGA6: molecular evolutionary genetics analysis version 6.0. Mol. Biol. Evol. 30(12): 2725-2729.

TERBORGH J., LOPEZ L., NUÑEZ P., RAO M., SHAHABUDDIN G., ORIHUELA G., RIVEROS M., ASCANIO R., ADLER G.H., LAMBERT T.D. \& BALBAS L. 2001. Ecological meltdown in predator-free forest fragments. Science. 294(5548):1923-6.

VALIÈRE, N. 2002. GIMLET: a computer program for analyzing genetic individual identification data. Mol. Ecol. Notes. 2(3): 377-379.

WAITS, L.P., LUIKART, G. \& TABERLET, P.2001. Estimating the probability of identity among genotypes in natural populations: cautions and guidelines. Mol. Ecol. 10: 249-256.

WULTSCH, C., WAITS, L.P., \& KELLY, M. J. 2016. A comparative analysis of genetic diversity and structure in jaguars (Panthera onca), pumas (Puma concolor), and ocelots (Leopardus pardalis) in fragmented landscapes of a critical Mesoamerican linkage zone. PloS one. 11(3), e0151043.

ZELLER, K. 2007. Jaguars in the new millennium data set update: the state of the jaguar in 2006. Wildlife Conservation Society, New York.

Received: 04/04/2017

Revised: 24/04/2017

Accepted: 01/05/2017

Published online: 22/05/2017 